\title{
Lost Boomerangs, the Rebound Effect and Transnational Advocacy Networks: A discursive approach to norm diffusion theory
}

\begin{tabular}{|c|l|}
\hline Journal: & Review of International Studies \\
\hline Manuscript ID & RIS-Apr-17-2444.R2 \\
\hline Manuscript Type: & Main Article \\
\hline Keywords: & $\begin{array}{l}\text { Burundi, gender, poststructuralism, Liberia, discourse, transnational } \\
\text { advocacy networks }\end{array}$ \\
\hline Subject Categories: & Explanatory International Relations Theory, Gender \\
\hline & $\begin{array}{l}\text { This article demonstrates that using a discursive approach to study } \\
\text { transnational advocacy networks helps understand better the outcomes of } \\
\text { norm diffusion in post-conflict contexts. I argue that constructivist } \\
\text { approaches to norm diffusion fall short as an explanation of norm adoption } \\
\text { because they assume an automatic process of norm propagation through } \\
\text { socialization mechanisms. The article first discusses how the internal } \\
\text { dynamics of discourse negotiation in transnational advocacy networks } \\
\text { impact the diffusion of international norms. The article then proposes the } \\
\text { concept of the rebound effect and to explore the conditions under which it } \\
\text { takes place. Through data collected during extended fieldwork, the paper } \\
\text { examines a prominent case, namely the transnational campaign for the } \\
\text { implementation of United Nations Security Council Resolution 1325 on } \\
\text { Women, Peace and Security in Burundi and Liberia. I ask why the } \\
\text { campaign was understood as a success in Liberia and as a failure in } \\
\text { Burundi. I argue that there is another way of looking at these cases in less } \\
\text { dichotomized ways. The article demonstrates how in both cases a very } \\
\text { particular discourse on gender security is (re)produced through power } \\
\text { relations between local and transnational activists limiting the type of } \\
\text { policies that are advocated for and depoliticising the grassroots. }\end{array}$ \\
\hline
\end{tabular}




\title{
Lost Boomerangs, the Rebound Effect and Transnational Advocacy Networks:
}

\section{A discursive approach to norm diffusion}

\begin{abstract}
This article aims to show the added value of studying transnational advocacy networks through a discursive approach in order to better understand the outcomes of norm diffusion in post-conflict contexts. I argue that constructivist approaches to norm diffusion fall short as an explanation of norm adoption because they assume an automatic process of norm propagation through socialization mechanisms. The first goal of the article is then to discuss how the internal dynamics of discourse negotiation in transnational advocacy networks impact the diffusion and implementation of international norms. The second goal is to propose the concept of the rebound effect and to explore the conditions under which it takes place. Through data collected during extended fieldwork, the paper examines a prominent case, namely the transnational campaign for the implementation of United Nations Security Council Resolution 1325 on Women, Peace and Security in Burundi and Liberia. I ask why and how the campaign was understood as a success in Liberia and as a failure in Burundi. I argue that there is another way of looking at these cases in less dichotomized ways. Crucially, my findings demonstrate how in both cases a very particular discourse on gender security is (re)produced through power relations between local and transnational activists limiting the type of policies that are advocated for and depoliticising the grassroots.
\end{abstract}

Keywords: Burundi, constructivism, gender, discourse, Liberia, norm diffusion, poststructuralism, Resolution 1325, subject-position, transnational advocacy networks 


\section{Introduction}

On 31 October 2000, the United Nations Security Council adopted Resolution 1325 on Women, Peace and Security (UNSCR1325) after intensive advocacy by a transnational advocacy network of feminist organisations constituting the UN NGO Working Group on Women, Peace and Security ${ }^{1}$. The network insisted on the fact that the Security Council needed to recognise the ways in which gender plays a role in conflict situations and in peacebuilding and security policies. The Resolution calls on UN institutions and Member States to prevent sexualized violence and other forms of violence against women during conflict, to protect women against such forms of violence and to ensure women's participation in decision-making and in peace and security governance. The unanimous vote at the Security Council of the Resolution sparked high hopes and enthusiasm from a transnational community of feminist activists who had managed to put gender security at the top of the global agenda. In contrast, there has been much cynicism about the way in which UNSCR1325 has been implemented as an international norm ${ }^{2}$, particularly through the drafting of National Action Plans (NAPs). These Plans designate measures, targets and benchmarks for the full implementation of UNSCR1325 in a specific country or region. In spite of the fact that, to a great extent, a coalition of international NGOs and local women's associations were behind the language of the different NAPs, local activists argue that their original intentions when campaigning for the implementation of UNSCR1325 and the drafting of NAPs in their

\footnotetext{
${ }^{1}$ The UN NGO Working Group on Women, Peace and Security is a consortium of 14 international NGOs with headquarters in New York whose mission is to conduct policy analysis, monitoring and advocacy for the implementation of the Women, Peace and Security Agenda.

${ }^{2}$ Keck and Sikkink define norms as "shared ideas, expectations and beliefs about appropriate behaviour" and they are "what gives the world structure, order and stability". Margaret Keck and Kathryn Sikkink, Activists Beyond Borders: Advocacy Networks in International Politics (Ithaca and London: Cornell University Press, 1998), p. 894.
} 
respective countries have been lost. ${ }^{3}$ They claim that a narrow understanding of gender security has deprived the Resolution from its transformative potential. ${ }^{4}$ Instead, it has become a sort of affirmative action model in which quotas for women in government, military and police institutions in post-conflict contexts have been adopted as a universal panacea for reducing sexual and gender-based violence in the aftermath of conflict, neglecting other representations of gender security. Nevertheless, the transnational advocacy network on Women, Peace and Security has qualified its campaign for the implementation of UNSCR1325 as a success in Liberia. ${ }^{5}$ Conversely, the implementation of UNSCR1325 in Burundi is qualified as a failure by international and local activists alike. ${ }^{6}$ In both cases UNSCR1325 has been used to encourage governments to implement quotas for women in government and in the security forces. In Liberia UNSCR1325 has also been successfully used by women's organisations to fight against sexual and gender-based violence, women organisations in Burundi have considered it a tool to advocate for the right to inherit land. These different approaches to advocacy have provoked disagreements between local activists and international organisations in Burundi on what the resolution is for. This observed variation represents a fascinating puzzle for International Relations and social movements' theory. Yet, it also represents a paradox for the existing constructivist literature on norm diffusion, which has advanced a particular understanding on how norms spread and become internalised in different contexts.

\footnotetext{
${ }^{3}$ WPSAC, Creating a transnational people's plan for UNSCR1325, available at: \{//wpsac.wordpress.com/2013/05/21/creating-a-transnational-peoples-plan-for-unscr-1325/\} accessed 27 June 2014.

${ }^{4}$ Audrey Reeves, 'Feminist knowledge and emerging govermentality in UN peacekeeping', International Feminist Journal of Politics, 14:3 (2012), pp. 348-369; Angela McRobbie, The aftermath of feminism: gender, culture and social change (Los Angeles and London: Sage Publications, 2009).

${ }^{5}$ Fieldwork notes, Monrovia, Liberia, August 2013.

${ }^{6}$ Fieldwork notes, Bujumbura, Burundi, April 2013. , Interview (a) INGO international staff member, Bujumbura, Burundi, 10 December 2012; Interview (b), ex-project manager for a national women organisation, Bujumbura, Burundi, 12 June 2012; Interview (c), staff member at UNWOMEN, Bujumbura, Burundi, 20 June 2012.
} 
Over the past 20 years, Liberia and Burundi have been marked by violent civil wars and international peace negotiations in which women participated as "representatives of women's civil society with an observer role". ${ }^{7}$ The two countries were chosen as case studies because the international community has seen them as good examples of female participation and a best practice to be promoted in the broader context of UNSCR1325. In Liberia, the Women of Liberia Mass Action Plan for Peace played a key role in the peace process ending the war in 2003. In Burundi, grassroots women's activities started right after the beginning of the war in 1993 and women's activists participated as observers in the Arusha Accords of 2003. In both cases a women's movement already existed locally prior to the arrival of international organisations, which was then helped in their efforts build larger networks and increase their visibility and budget.

In explaining the emergence, institutionalisation and internalisation of international norms, the literature on norm diffusion has given a critical role to norm entrepreneurs, such as epistemic communities, ${ }^{8}$ international organisations ${ }^{9}$ and transnational advocacy networks (TANs). ${ }^{10}$ True and Mintrom demonstrate that the diffusion of international norms on gender mainstreaming is made possible by the role played by TANs,

\footnotetext{
${ }^{7}$ UNIFEM, "Women's Participation in Peace Negotiations: Connections between Presence and Influence" (New York: UNIFEM), August 7, 2010.

${ }^{8}$ Peter Haas, Knowledge, power, and international policy coordination (Columbia CA: University of California Press, 1997).

${ }_{9}^{9}$ Martha Finnemore, National Interests in International Society (Ithaca NY: Cornell University Press, 1996).

${ }^{10}$ Transnational Advocacy Networks comprise "relevant actors working internationally on an issue, who are bound together by shared values, a common discourse, and dense exchanges of information and services". Margaret Keck and Kathryn Sikkink, Activists Beyond Borders: Advocacy Networks in International Politics (Ithaca and London: Cornell University Press, 1998). These include international and domestic NGOs, social movements, international organisations, national governments and individuals.
} 
particularly by the transnational feminist movement. ${ }^{11}$ Working through a boomerang effect, TANs can help local social movements gain leverage and information to circumvent domestic indifference or apply pressure by transferring the debate to the international level. ${ }^{12}$ Although the formation of a TAN almost always results in struggles over the meaning of norms, in which "frame disputes can be a significant source of change within networks", ${ }^{13}$ once a norm is created and a new advocacy campaign is put in place for its implementation in local contexts, the norm is no longer understood as vulnerable to contestation. ${ }^{14}$ Constructivist approaches obscure the potential of local constituencies in navigating this contestation when diffusion and implementation of norms is depicted as unambiguous. ${ }^{15}$

By taking up Bucher's proposition to focus on norm politics rather than on norm diffusion, ${ }^{16}$ this article does two things. First, it points to an alternative conception of norm theory that focuses on productive power and on the co-constitution of agents and the norms for which they advocate. Second, the article develops the concept of the rebound effect to identify discursive shifts during the campaign for the implementation of an international norm. The rebound effect refers to the moment where the intelligibility boundaries between the thrower of the boomerang and the receiver are so impervious that the boomerang bounces back and never reaches its destination. Such a

\footnotetext{
11 Jacqui True and Michael Mintrom, 'Transnational networks and policy diffusion: The case of gender mainstreaming', International Studies Quarterly, 45: 1 (2001), pp. 27-57.

${ }^{12}$ Keck and Sikkink (1998), p. 12; Donatella Della Porta and Sidney Tarrow, (eds) Transnational protest and global activism (London: Rowman \& Littlefield Publishers, 2005).

${ }^{13}$ Keck and Sikkink (1998), p. 8

${ }^{14}$ Mona Krook and Jacqui True, 'Rethinking the life cycles of international norms: The United Nations and the global promotion of gender equality', European Journal of International Relations, 18:1 (2012), pp. 103-127.

${ }^{15}$ Kees Van Kersbergen and Bertjan Verbeek, 'The politics of international norms: Subsidiarity and the imperfect competence regime of the European Union', European Journal of International Relations, 13:2 (2007), pp. 217-238.

${ }^{16}$ Bernd Bucher, 'Acting abstractions: Metaphors, narrative structures, and the eclipse of agency', European Journal of International Relations, 20:3 (2014), pp. 742-765.
} 
rebound may be the result of exclusion or annulment of certain subject positions and discourses.

The article follows a discursive approach to norm diffusion that identifies norms as processes. ${ }^{17}$ I argue that this approach helps us understand better not why norms diffuse, but rather the outcome of that diffusion. That is, how a particular understanding of a norm is fixed and how this implies a particular "politics of reality". ${ }^{18}$ Like other feminist scholars who have raised concerns about the accountability and representativeness of TANs, ${ }^{19}$ I show how certain understandings and subject positions come to be excluded, shifted, annulled or incorporated in the (re)production of international norms. I follow critical strands of norm analysis, which have apprehended norms as not simply diffusing from one site to another, but rather as conveyers of various exclusions in the international system. ${ }^{20}$ More specifically, I use a discursive approach in order to identify and untangle the power relations and normative structures involved in, and the political implications of, the competing and contradictory constructions of the concept of gender security as a master frame for the implementation campaign of the UNSCR1325 on WPSomen, Peace and Security in Burundi and in Liberia.

\footnotetext{
${ }^{17}$ Krook and True (2012).

${ }^{18}$ Maja Zehfuss, Constructivism in international relations: the politics of reality (Cambridge: Cambridge University Press, 2002).

${ }^{19}$ Vandana Desai, 'NGOs, gender mainstreaming, and urban poor communities in Mumbai', Gender and Development, 13:2 (2005), pp. 90-98; Breny Mendoza, 'Transnational Feminisms in Question', Feminist Theory, 3 (2002), pp. 295-314.

${ }^{20}$ Rebecca Adler-Nissen, 'Stigma management in international relations: transgressive identities, norms, and order in international society', International Organization 68:1 (2014), pp. 143-176; Ayşe Zarakol, 'What made the modern world hang together: socialisation or stigmatisation?' International Theory, 6:2 (2014), pp. 311-332; Charlotte Epstein, The power of words in international relations: birth of an antiwhaling discourse (Boston: MIT Press, 2008).
} 
The next section provides an overview of different approaches to norm diffusion and norm contestation, as well as their shortcomings. The subsequent sections offer a discursive reading of norm diffusion theory. First, I outline the research design and methodology. Second, based on significant fieldwork, including the use of semistructured interviews and participant observation in Burundi and Liberia during 2012 and 2013, the paper uses the campaign for the implementation of UNSCR1325 in both countries in order to demonstrate how previous approaches ultimately take for granted the fixedness of the content of a norm, limiting its possible meanings as well as the range of conceivable implementation practices. Third, the paper uses a discursive approach to norm diffusion and the concept of the rebound effect to propose an alternative reading. I argue that this reading offers a better explanation on the outcomes of norm diffusion and on the impact of the interaction between transnational and domestic actors on processes of norm implementation. Finally, the paper discusses how this approach could improve further theory development and comparative empirical research in similar post-conflict contexts.

\section{A literature review on norm diffusion theory}

This section argues that although good at explaining how norms come into existence and why advocacy networks form, all variants of norm diffusion theories do poorly at explaining the outcomes of international norm diffusion and their implementation in national and local contexts. ${ }^{21}$ First, they fall short as an explanation of the internal constitution of norm diffusion by assuming an automatic process of norm propagation,

\footnotetext{
${ }^{21}$ Finnemore and Sikkink, 1998; Keck and Sikkink, 1998; Ethan Nadelmann, 'Global prohibition regimes: The evolution of norms in international society', International Organization, 44:4 (1990), pp. 479-526; Rodger Payne, 'Persuasion, frames and norm construction', European journal of international relations, 7:1 (2001), pp. 37-61.
} 
where norms "acquire life on their own", ${ }^{22}$ once a critical mass of actors automatically adopt a norm and its content. Second, they have neglected the performative dimension running through this "automatic" process of norm propagation, in which identities and ideas are co-constituted. Consequently, they reproduce existing hierarchies in the international system, in which local civil society activists are constituted by the international, but do not have the capacity to constitute, resist, subvert and transform.

The first critique of the literature relates to the way in which it accounts for the internal constitution of international norms as "shared understandings". ${ }^{23}$ Most scholars have presented a very static and linear conceptualisation of the life cycle of international norms ${ }^{24}$ where norm entrepreneurs are able to form a transnational advocacy campaign to push for the creation of a new norm ${ }^{25}$ and then help local activists diffuse it in domestic contexts. ${ }^{26}$ This understanding assumes that this 'new' norm did not exist already and was not implemented in the domestic context, particularly in developing and post-conflict states. ${ }^{27}$ In addition, norm diffusion is treated as a dynamic process, but the content of the norm is considered as a stable concept. This understanding is contradicted by the empirical observation that people have different understandings of the same norm and that therefore, there are different interpretations of the practices and

\footnotetext{
${ }^{22}$ Bucher (2014), p. 748.

${ }^{23}$ Friedrich Kratochwil, "Rules." Norms and Decisions: On the Conditions of Practical and Legal Reasoning in International Relations and Domestic Affairs (Cambridge: Cambridge University Press, 1989).

${ }^{24}$ Audie Klotz and Cecilia Lynch, Strategies for research in constructivist international relations (New York: ME Sharpe, 2007); Finnemore and Sikkink (1998); Martha Finnemore, The purpose of intervention: Changing Beliefs about Intervention (Ithaca, NY: Cornell University Press, 2003); Richard Price, 'Reversing the gun sights: Transnational civil society targets land mines', International Organization, $52: 3$ (1998), pp. 613-644.

${ }^{25}$ Jutta Joachim, Agenda Setting, the UN and NGOs: Gender Violence and Reproductive Rights (Washington: Georgetown University Press, 2007).

${ }^{26}$ Thomas Risse, Stephen Ropp and Kathryn Sikkink, The Power of Human Rights: international norms and domestic change (Cambridge, UK: Cambridge University Press, 1999).

${ }^{27}$ Ryan and Basini explain how many of the provisions contained in UNSCR1325 were already being implemented in Liberia and Sierra Leone before being named as such. Caitlin Ryan and Helen Basini, 'UNSC Resolution 1325 national action plans in Liberia and Sierra Leone: An analysis of gendered power relations in hybrid peacebuilding', Journal of Intervention and Statebuilding, 11:2 (2017), pp. 186-206.
} 


\footnotetext{
${ }^{28}$ Amitav Acharya, 'How Ideas Spread: Whose Norms Matter? Norm Localization and Institutional Change in Asian Regionalism', International Organization, 58: 2 (2004), pp. 239-275; Andrew Cortell and James Davis, 'When norms clash: international norms, domestic practices, and Japan's internalisation of the GATT/WTO', Review of International Studies, 31: 1 (2005), pp. 3-25; Jeffrey Checkel, 'International institutions and socialization in Europe: Introduction and framework', International organization, 59:4 (2005), pp. 801-826; Lisbeth Zimmermann, 'Same same or different? Norm diffusion between resistance, compliance and localization in post-conflict states', International Studies Perspectives, 17:1 (2016).

${ }^{29}$ Cristina Badescu and Thomas Weiss, 'Misrepresenting R2P and Advancing Norms: An Alternative Spiral?' International Studies Perspectives, 11:4 (2010), pp. 354-374.

${ }^{30}$ David Capie, 'The responsibility to protect norm in Southeast Asia: framing, resistance and the localization myth', The Pacific Review, 25: 1 (2012), pp. 75-93.

${ }^{31}$ Nicole Deitelhoff and Lisbeth Zimmermann, Things we lost in the fire: How different types of contestation affect the validity of international norms. (Frankfurt am Main: PRIF Working Papers, 2013).

${ }^{32}$ Cortell and Davis (2005).

${ }^{33}$ Ryder McKeown, 'Norm regress: US revisionism and the slow death of the torture norm', International Relations, 23: 1(2009), pp. 5-25.

${ }^{34}$ Acharya (2004); Amitav Acharya, 'Norm Subsidiarity and Regional Orders: Sovereignty, Regionalism, and Rule-Making in the Third World', International Studies Quarterly, 55 (2011), pp. 95-123.

${ }^{35}$ Susanne Zwingel, 'How do Norms Travel? Theorizing International Women's Rights in Transnational Perspective', International Studies Quarterly, 56 (2012), pp. 115-129.

${ }^{36}$ Gergana Noutcheva, 'Fake, partial and imposed compliance: the limits of the EU's normative power in the Western Balkans', Journal of European Public Policy, 16:7 (2009), pp. 1065-1084.

${ }^{37}$ Ryan Goodman and Derek Jinks, 'Incomplete internalization and compliance with human rights law', European Journal of International Law, 19: 4 (2008), pp. 725-748.

${ }^{38}$ Antje Wiener, 'Contested compliance: Interventions on the normative structure of world politics', European Journal of International Relations, 10: 2 (2004), pp. 189-234.

${ }^{39}$ Roger Mac Ginty, International peacebuilding and local resistance: hybrid forms of peace (London: Palgrave Macmillan, 2011).

${ }^{40}$ Kratochwil (1989); Mervyn Frost, Ethics in International Relations: a constitutive theory (Cambridge: Cambridge University Press, 1996); James Davis, Terms of Inquiry: on the theory and practice of political science (Baltimore: JHU Press, 2005).

${ }^{41}$ Antje Wiener, 'Enacting meaning-in-use: qualitative research on norms and international relations', Review of International Studies, 35:01 (2009), pp. 175-193.
} 
diffuse and norms cascade" mechanically. ${ }^{42}$ Even the most critical scholars propose models that only permit cultural adaptation to local norms - localization- or translation to the domestic context that do not contest "the core of its fixed meaning". ${ }^{43}$ Hence, norm conceptualisation is particularly problematic when it comes to explain transnational campaigns for norm diffusion in domestic contexts and the intersubjective ontology of norms in a "constant process of negotiating and re-negotiating" ${ }^{44}$ That is, "despite emphasis on the dynamic nature of actor behaviour, behavioural change is appraised as the passage from one stable state to another along the trajectory of internalization of a new norm". ${ }^{45}$ More recently, scholars such as Betts and Orchard have tried to overcome the static and linear conception of the internalization trajectory by differentiating between two distinct, but simultaneous, processes: institutionalisation, which primarily reflects an international process, and implementation, triggered at national level once the state commits to the new norm. ${ }^{46}$ They argue that these processes feed into one another and that national dynamics can reverse international progress on norm making. Even with this additional insight, their model is still one where international actors design norms that are then disseminated into national contexts. Ultimately, institutionalisation and implementation are not differentiated processes, but rather they constitute the same process that is taking place at different levels of analysis - the international and the domestic. More particularly on the implementation of the UNSCR1325 in post-conflict settings, Irvine proposes the concept of the "double

\footnotetext{
42 Bucher (2014), p. 742.

${ }^{43}$ Holger Niemann and Henrik Schillinger, 'Contestation 'all the way down'? The grammar of contestation in norm research', Review of International Studies, First view (2017), pp. 1-21. 
boomerang effect" ${ }^{47}$ She argues that in post-conflict situations where international actors play a crucial role, the simple boomerang mechanism, by which international actors help local activists force a state to comply with a norm is not enough. Indeed, in the Balkans, local women organisations added a reverse boomerang, by which they mobilised local support to make the international community comply with their own norm. Although it offers the tools to study two levels of analysis at the same time, the double boomerang does not question either the shared understanding of what UNSCR1325 means or what policies need to be put in place.

The second weakness of constructivist models to explain the outcomes of norm diffusion is related to the fact that advocacy networks and their local beneficiaries are understood as constituting a stable platform of interest, identity and shared meaning through a process of socialization, ${ }^{48}$ rather than being a "contingent outcome" of social interaction. ${ }^{49}$ For example, Finnemore and Sikkink highlight how "conformity and esteem" are needed in the socialization process into a new norm. ${ }^{50}$ The model fails to take into account the performative dimension of individual and collective identity, by which an actors' understanding evolves with the circumstances and within a complex network of interdependencies. ${ }^{51}$ A common identity and a common master frame are therefore not something that precedes collective action in a TAN, but something that gets constructed, negotiated and developed through performances in campaigning for the creation, institutionalization and implementation of an international norm. As

\footnotetext{
47 Jill Irvine, 'Leveraging Change', International Feminist Journal of Politics, 15:1 (2012), pp. 20-38.

${ }^{48}$ Cass Sunstein, 'Social norms and social roles', Columbia law review, 9: 4 (1996), pp. 903-968; Peter Katzenstein, The Culture of National Security: Norms and Identity in World Politics (New York: Columbia University Press, 1996); Finnemore and Sikkink (1998).

49 Judith Renner, Discourse, Normative Change and the Quest for Reconciliation in Global Politics (Manchester: Manchester University Press, 2013).

${ }^{50}$ Finnemore and Sikkink (1998), pp. 903-904.

${ }^{51}$ Xavier Guillaume, 'Unveiling the 'International': Process, Identity and Alterity', Millennium: Journal of International Studies, 35: 3 (2007), pp. 741-759; Nicholas Onuf, World of our Making (Columbia, SC: USCP, 1989).
} 
performative, this identity is fluid and unstable, and therefore, in continuous negotiation. Consequently, TANs are not stable socialization platforms where meaning is shared, but rather performing sites of struggle for meaning of norms, identities and interests.

The concept of socialization implies a universalization of what necessarily is a localized set of values and beliefs, as well as a conceptualization of a movement that runs in one direction: from the international to the local, silencing the voice of the latter. ${ }^{52}$ This conceptualisation denies the option that these norms themselves are under contention between activists, ${ }^{53}$ leaving only two possibilities: either a boomerang effect will take place if international and local activists decide to cooperate; or nothing will happen at all if cooperation is deemed impossible.

Furthermore, it is argued that phenomena such as socialisation and information cascades are in part the result of some idea sharing and persuasion on certain values and principles defended in the norm to be implemented, not only on states and decisionmakers, but also amongst members of a transnational campaign. ${ }^{54}$ However, to place all causal explanation on the principle in itself as the driver of the process of norm socialisation means that some ideas or principles are inherently better or more right than others, depoliticising and naturalising them, forgetting that any form of "socialization inherently involves discursive inequalities" ${ }^{, 55}$ and material differences. It becomes difficult to appreciate that norm qualities are part of processes of knowledge production and political construction. Ayoub, for example, shows how new EU member-states

\footnotetext{
52 Charlotte Epstein, 'Stop Telling Us How to Behave: Socialization or Infantilization?', International Studies Perspectives, 13 (2012), pp. 135-145.

${ }^{53}$ Shareen Hertel, Unexpected Power. Conflict and Change among Transnational Activists, (Ithaca and London: Cornell University Press, 2006).

${ }^{54}$ Zachary Elkins and Beth Simmons, 'On waves, clusters, and diffusion: A conceptual framework', The Annals of the American Academy of Political and Social Science, 598: 1 (2005), pp. 33-51. ${ }^{55}$ Audie Klotz and Cecilia Lynch, Strategies for research in constructivist international relations (New York: ME Sharpe, 2007), p. 92.
} 
exposed to similar norms and regulations differ greatly in their social attitudes and legal implementation of international norms on sexual minorities. He demonstrates how this variation has to do with visibility of activists at national level ${ }^{56}$ and the perceived threat they pose to the cohesion of the state. ${ }^{57}$ Looking at intranetwork dynamics, Hertel claims that different normative understandings within networks can have a significant impact on both norms evolution and policy outcomes as different norm interpretations are in competition with one another. ${ }^{58}$ Consequently, contestation of norms emerge not only from an overlap with other culturally specific norms, but from different interpretations and ideas contained in those norms. ${ }^{59}$

I argue that social power relations within a TAN performed through the discursive practices of its activists will play a role in determining not only how norms are understood, adopted and propagated, but also how local grievances are constructed. Studying intranetwork dynamics of transnational advocacy networks involved in norm diffusion deviates the focus of the study from how "the ought becomes the is" "an ought is made an is". ${ }^{61}$ Ultimately, I argue that looking at norm diffusion as discourse and subject positions reproduction or contestation amongst the members of advocacy networks provides insight into how to "theorize with the unfixity" 62 of norm meaning.

\footnotetext{
${ }^{56}$ Phillip Ayoub, When States Come Out: Europe's Sexual Minorities and the Politics of Visibility, (New York: Cambridge University Press, 2016).

${ }^{57}$ Phillip Ayoub, 'Contested Norms in New-Adopter States: International Determinants of LGBT Rights Legislation', European Journal of International Relations, 21:2 (2015), pp. 293-322.

${ }^{58}$ Hertel (2006)

${ }^{59}$ Krook and True (2012), p. 104.

${ }^{60}$ Finnemore and Sikkink (1998), p. 916.

61 Bucher (2014), p. 755.

${ }^{62}$ Charlotte Epstein, 'Constructivism or the eternal return of universals in International Relations. Why returning to language is vital to prolonging the owl's flight', European Journal of International Relations, 19:3 (2013), p. 501.
} 


\section{A note on discourse as theory and methodology}

This article follows the line of critical constructivism and post-structuralism-influenced discourse analysis methodology. ${ }^{63}$ I follow a foucauldian understanding of power as a "productive network which runs throughout the whole social body". ${ }^{64}$ Power is not something that can be owned, but rather power produces and is produced through social relations, through the practices of actors or subjects, and these practices also determine the boundaries of what can and cannot be said and who can and cannot speak. ${ }^{65}$ Epstein's work on the analysis of the international whaling regime offers a far-reaching approach on discursive power relations in an advocacy campaign and how they determine the imposition of what is considered acceptable and not. This means that advocacy campaigns aimed at shifting policy and politics are made "in and through language", ${ }^{66}$ through key concepts as crucial sites of political struggle. These key concepts are 'inescapable, irreplaceable parts of the political and social vocabulary' which become fixed as a single signifier that contains a range of different meanings. ${ }^{67}$

Following this poststructuralist logic, a discourse is not simply language, but rather it is a system of significations and representations that fixes certain interpretations of the

\footnotetext{
${ }^{63}$ Stephan Engelkamp and Katharina Glaab, 'Writing Norms: Constructivist Norm Research and the Politics of Ambiguity', Alternatives, 40: 3-4 (2015), pp. 201-218; Charlotte Epstein, The power of words in international relations: birth of an anti-whaling discourse (Boston: MIT Press, 2008); Lene Hansen, Security as Practice: Discourse Analysis and the Bosnian War (London: Routledge, 2006); Laura Shepherd, Gender, Violence and Security: Discourse as Practice (London: Zed 2008).

${ }_{64}$ Michael Foucault, The History of Sexuality, Vol 1: An Introduction (New York: Vintage Books, 1990), p. 119.

${ }^{65}$ Hansen (2006)

${ }^{66}$ Sam Cook, 'The 'woman-in-conflict' at the UN Security Council: a subject of practice', International Affairs, 92: 2 (2016), p. 355.

${ }^{67}$ Melvin Richter and Michaela Richter, "Introduction: Translation of Reinhart Koselleck's" Krise," in Geschichtliche Grundbegriffe', Journal of the History of Ideas, 67: 2 (2006), pp. 343-356.
} 
world, reproducing power relations. ${ }^{68}$ However, due to their ambiguity and abstraction, these representations are only fixed in a temporary and incomplete manner. ${ }^{69}$ Activists have to constantly confront a multiplicity of competing discourses or master frames ${ }^{70}$ that form the connections between subjects and objects, and provide 'subjects positions with which social agents can identify'. ${ }^{71}$ Under this framework, the rebound effect enables us to think about the power relations involved in norm spreading, ${ }^{72}$ as it determines the limit between the discourses and subject positions accepted by the TAN and those that reach deaf ears. Such an approach facilitates a study of the iterative norm contestation and negotiation process, as state and non- state actors compete to identify, define and implement a policy. ${ }^{73}$ In this approach, discourses and subject positions are perceived as the consequence and not the cause of interactions amongst activists.

The collective "I/We" versus the "Other" activists' identity is therefore produced in a very precise way, as the subject position is established when the subject speaks within a particular discourse. ${ }^{74}$ In our case, the subject who speaks of a gender security as socioeconomic security, discards and positions itself outside the security as affirmative action discourse proposed by the "Other". It is a much more dynamic and active process than the static identity acceptance of constructivist models or the culturalist explanations that presume change and contestation comes from cultural validation. ${ }^{75}$ An actor takes up and transforms an understanding of a norm rather than internalizing a discursive

\footnotetext{
${ }^{68}$ Shepherd (2008), pp. 20-23.

${ }^{69}$ Ernesto Laclau and Chantal Mouffe, Hegemony and socialist strategy (London: Verso, 1985)

${ }^{70}$ Robert Benford, 'Master Frame', in David Snow, Donatella della Porta, Bert Klandermans and Doug McAdam (eds), The Wiley-Blackwell Encyclopedia of Social and Political Movements (New York: WileyBlackwell, 2013).

${ }^{71}$ David Howard, Aletta Norval and Yannis Stavrakakis, Discourse Theory and Political Analysis. Identities, Hegemonies and social Change (Manchester: Manchester University Press, 2000), p. 4.

72 Bucher (2014), p. 750.

${ }^{73}$ Krook and True (2012)

${ }^{74}$ Epstein (2008)

${ }^{75}$ Zehfuss (2002), p. 92
} 
construction of gender security through a socialization process. ${ }^{76}$ Agency and collective identities emerge from the subject-position given by a certain discursive construction of gendered subjects in global politics, ${ }^{77}$ while other subject positions are precluded, allowing or foreclosing the possibilities for future actions, including those actions pertaining to the implementation efforts of UNSCR1325 in Burundi and Liberia. This also makes activists not only subjects of discourse as they would be in a rigorous poststructuralist approach, but also powerful agents able to privilege and evaluate the advocacy network discourses and master frame according to their position. ${ }^{78}$

Discourse analysis techniques have been applied to a wide variety of texts from reports and memorandums, ${ }^{79}$ to policy documents ${ }^{80}$ and even news media. ${ }^{81}$ Shepherd engages with interview transcripts as legitimate discursive artefacts "rather than individual 'truths' about a given context". ${ }^{82}$ I focus my analysis on both, my 600 pages of transcripts generated by more than 60 semi-structured interviews and policy documents as discursive artefacts allowing for the examination of a wide range of discursive practices. The interview transcripts in particular provide a rich 'counter-archive' of knowledge about (gendered) threats and (in) security. ${ }^{83}$ This permits a more democratic account on the analysis of norm diffusion, because it includes voices that rarely print their discourses in written documents, such as rural women activists in post-conflict

\footnotetext{
${ }^{76}$ Jeffrey Checkel, 'International institutions and socialization in Europe: Introduction and framework', International organization, 59: 04 (2005), pp. 801-826.

${ }^{77}$ Hansen (2006); Shepherd (2008); Laura Shepherd, 'Gendering Security', in Burgess P (ed.), Handbook of New Security Studies (London: Routledge, 2010), pp. 72-80.

${ }^{78}$ Eschle (2013)

${ }^{79}$ Lee Jarvis, Times of Terror: Discourse, Temporality and the War on Terror (Basingstoke: Palgrave Macmillan, 2009); Jutta Weldes, 'Constructing national interests', European Journal of International Relations, 2:3 (1996), pp. 275-318.

${ }^{80}$ Penny Griffin, Gendering the World Bank: Neoliberalism and the gendered foundations of global governance (London: Palgrave Macmillan, 2009); Shepherd 2008.

${ }^{81}$ Francois Debrix, Tabloid terror: War, culture and geopolitics (London: Routledge, 2008).

82 Laura Shepherd, 'Constructing civil society: Gender, power and legitimacy in United Nations peacebuilding discourse', European Journal of International Relations, $21: 4$ (2015), pp. 890.

${ }^{83}$ Michael Shapiro, Studies in Transdisciplinary Method: After the Aesthetic Turn (London: Routledge, 2013), p. 85.
} 
Burundi and Liberia. A detailed deconstruction of the rhetorical structure and predicates in these texts is undertaken in order to expose continuities and shifts in the constructions of a master frame on gender security.

Through the empirical material obtained during several months of fieldwork, I studied the most recurrent combinations of the discourses on gender security in the advocacy campaign to implement UNSCR1325 in Burundi and Liberia. The aim of the analysis is to obtain certain discursive identification or "predication/subject positioning" ${ }^{84}$ For example, some international activists have declared that attempts by some Burundian activists to include the right to inherit as part of the UNSCR1325 implementation campaign was to go too far because it was not to be found in any part of the resolution. ${ }^{85}$ That is, discursive identification redefines not only what is possible to say - or what the boomerang will collect - but also what is not possible to say - or what will rebound. It refers to the creation of new horizons of possibility regarding what is heard in discourse. In conceptualizing discursive identification I use a political ontology that takes into account features of gender security discourses such as conflict, processes of inclusion and exclusion, and power relations. This illuminates the examination of subject positioning in terms of a "process of linking", whereby a series of discourses are connected to a particular subject position, and a "process of differentiation", whereby these discourses try to differentiate a certain identity from their opposite. ${ }^{86}$

\footnotetext{
${ }^{84}$ Shepherd (2008)

${ }^{85}$ Several interviewees - INGOs staff and local NGOs staff - noted this fact.

${ }^{86}$ Hansen (2006), pp. 19-21.
} 


\section{Contested frames of mobilization for gender security}

Conceptualizations of both gender and security rest upon a particular set of logics understood as "the ways in which various concepts are organized within specific discourses". ${ }^{87}$ A particular logic of gender security depends on how "gender" and "security" are constructed as well as the "assumptions that inform them and the policy prescriptions that issue from them". ${ }^{88}$ There are different logics of what "gender security" might look like. ${ }^{89}$ We are thus enjoined to enquire into "multiple and competing discourses about gender ... and security ... [which] articulate specific subjects, ascribe identities to these subjects and position them in relation to each other', ${ }^{90}$ This is important because when a state has been unwilling to implement international or national legislation, local civil society organizations will try to bypass their state and send a boomerang to directly search out international allies and bring pressure on their national government. In our case, a coalition between local and international allies will only work if their gender and security logics are compatible. That is, the boomerang effect only takes place when activists forming a transnational advocacy network share compatible discourses that can be contained in the same master frame. Otherwise, the boomerang sent by local activists will bounce back because differing logics of gender and of security held by international allies might be based on incompatible sets of assumptions and policy prescriptions. This will result in the rebound effect.

\footnotetext{
${ }^{87}$ Laura Shepherd, "'To Save Succeeding Generations from the Scourge of War": The US, UN, and the Violence of Security', Review of International Studies, 34: 2 (2008), p. 294.

${ }^{88}$ Shepherd (2008), p. 294.

${ }^{89}$ Laura McLeod, 'Configurations of post-conflict: Impacts of representations of conflict and postconflict upon the (political) translations of gender security within UNSCR 1325', International Feminist Journal of Politics, 13: 4(2011), p. 595.

${ }^{90}$ Shepherd (2010), p. 76.
} 
I found five recurring combinations of discourses on gender security amongst the activists taking part in the international advocacy campaign for the implementation of UNSCR1325 in Burundi and Liberia. ${ }^{91}$ These 5 discourses on gender security are ideal types for analysis and by no means isolated from other discourses or from elements of other discourses. The objective here is not to establish a typology of discourses, but rather to understand the meaning of interactions amongst them. As ideas and agents are co-constituted, the discursive combinations found below also represent a certain subject-position and are promoted almost uniformly by a certain type of actor (governmental, grassroots group, NGO). I argue that the master frame on gender security for the implementation campaigns of UNSCR1325 in Burundi and Liberia could have been constructed otherwise, but the particular power asymmetries within the TAN have promoted the use of a discourse on gender security understood as civil and political equality. Other sets of articulations and meanings proposed were discarded. The discourses are contained in a table that should be read from up to down, starting from the first discourse on gender security as inclusion, which is the discourse contained in the UNSCR1325, and ending with the last discourse on gender security as reconceptualization of spaces, which is the discourse produced mostly by rural grassroots women organizations. Presenting discourses on a scale, from those closer to the Resolution to those that are further away in the scale of representations and subjectpositions offers the advantage of identifying which discourses are going to be accepted by the TAN as adequate for the campaign on the implementation of UNSCR1325 in Burundi and Liberia and which discourses are going to be discarded because of their unintelligibility.

\footnotetext{
${ }^{91}$ I found inspiration for this approach on previous similar work conducted by Laura McLeod (2011) and Catherine Eschle (2013)
} 
Gender Security as inclusion of women in peacebuilding and decision-making instances

This frame is put forward by the Security Council and is contained in the drafting of UNSCR1325. It is based upon the logic that full participation of women in political instances and in security forces, such as military bodies or the police, are the best means to achieve sustainable peace. The idea is that female decision-makers and female peacekeepers are expected to have the social skills and innate characteristics of a peaceful and caring individual male decision-makers or military lack. ${ }^{92}$ The female subject is understood as the perfect peacebuilder and consequently, if UN institutions and post-conflict countries improve gender balance in public institutions and security governance structures, episodes of gender insecurity will disappear or at least diminish. Indeed, certain international NGOs, such as International Alert and Human Rights Watch organized workshops on the Women, Peace and Security Agenda and funded local associations who started working as NGOs at the beginning of the 2000's in post-

\footnotetext{
92 Heidi Hudson, 'A double-edged sword of peace? Reflections on the tension between representation and protection in gendering liberal peacebuilding', International Peacekeeping, 19: 4 (2012), pp. 443460.
} 
conflict countries such as Burundi and Liberia with the help of UNIFEM, the EU, USAID and other donors. As one international NGO worker in Burundi put it:

"We hired two women as coordinators of our project for peacebuilding and they set up a network of informal groups in a lot of the provinces [...] They have a captive audience to which we can provide training and capacity building. "93

Initially, international NGOs are looking for groups that can serve as motors of peacebuilding. One of these two women hired as a coordinator described herself by using the discourse in which women are inherently peaceful, making for excellent peacemakers:

"And why use women? Because women are more sensible. A woman does not cut her neighbor's throat, and then a woman carries children in her womb. So if she carries a baby inside her during 9 months, it is not easy for her to cut a kid's throat. So it was good to make these women peacemakers because they have a heart. [...] And because women are not immediate actors in the war, they are going to be able to determine easily what are the causes of the war, they will be able to tell you what she saw and what she thought." 94

\section{Gender Security as equality before the law}

This frame is deployed in the NAPs of Burundi and Liberia. ${ }^{95}$ It represents the views of the national experts who, with the help of international NGOs and UNWOMEN

\footnotetext{
${ }^{93}$ Interview (a)

${ }^{94}$ Interview (b)

${ }^{95}$ Government of Burundi, Plan d'Action National pour la mise en oeuvre de la Résolution 1325, 2011, available at : \{http://www.peacewomen.org/assets/file/NationalActionPlans/burundi nap 2012-16.pdf\}
} 
personnel, drafted the NAPs. These experts are activists coming from national women associations, governmental actors, and local staff working for missions of international organizations. This frame is based on a subject position of a woman-in-action who is the main character of the struggle for women's rights against a patriarchal culture and traditional practices that render women second-class citizens and as servants of men. It implies a justification for the creation of women-only organizations funded by international donors and trying to connect private and public spheres in order to change cultural patterns of gender roles conduct in society. Connected with these progressive assumptions is the logic that instrumental equality through the law is a way of achieving gender security. The recommendations for the draft NAPs in Burundi and Liberia emphasize measurable, quota-based indicators of the participation and involvement of women in the Burundian and Liberian government and defense sector. As illustrated below, security is understood as quantitative equality in state processes and structures. In this frame, rather than shifting the meaning and subject of security, gender security is about inclusion of groups currently not involved in government or involved in reforming the security sector processes.

"Some argue that ok, numerically, we have a lot of women in politics, but beyond that, has anything changed? Personally, I think it is a social change. People say that women in the institutions are not there to serve the interests of women, but the interests of the whole of the population. And so it is not an easy issue. So now what we are doing is to work with women in Parliament and to explain their role in the National Assembly. "96

\footnotetext{
accessed 14 April 2017; Government of Liberia, The Liberian National Action Plan for the Implementation of United Nations Resolution 1325, 2009, available at:

http://www.peacewomen.org/assets/file/NationalActionPlans/liberia_nationalactionplanmarch2009.pd f\} accessed 14 April 2017.

${ }^{96}$ Interview (c)
} 


\section{Gender Security as countering sexual violence}

This frame is promoted by donors, international NGOs and leaders of the women's movement in Liberia. It emphasizes that the core regulatory preoccupation on the WPS agenda has to be sexual violence in war and post-war settings, and in particular "rape as a weapon of war". It establishes therefore an understanding of women as victims of male (sexual) violence. Any discussion of other types of gender security are distinctly cut off from rape discourses, and impunity analysis has no connection to advocacy around advancing economic and political equality for women. Notably it is rape that has garnered the most international legal and policy discourse and action, sharing the logics underpinning events such as the Global Summit to end Sexual Violence in Conflict that took place in London June 10-12 2014, co-chaired by British Foreign Secretary William Hague and Angelina Jolie, Special Envoy for the UN High Commissioner for Refugees. Indeed, for this frame the WPS agenda is mostly about sex. This type of frame is very present in Liberia, where women's organisations use funds to promote campaigns related to rape and HIV/Aids or infant rape.

\section{Gender Security as freedom}

This frame is mostly used by leaders of urban, national women's organizations. Based on a feminist perspective on human security, ${ }^{97}$ this frame offers a subject position of the woman as an individual who should be free from fear - physical security - and free from want - socioeconomic security in their private and public lives. It is based upon the logics that there is a lack of accountability from the part of the governmental institutions that ensure an environment in which the interrelated nature of gender inequality and the sociocultural, biological, economic and political subordination of women should be

\footnotetext{
${ }^{97}$ Heidi Hudson, 'Doing security as though humans matter: A feminist perspective on gender and the politics of human security', Security Dialogue, 36:2, pp. 155-174.
} 
challenged. The solution is to transform the institutional and legal landscape that separates socio-economic and physical security:

"Gender security means a lot of things. A girl needs to be leading an acceptable life; she cannot be having worse living conditions than a man just because she is a woman. So there is economic security and then also physical security, you know, people victims of rape and gender-based violence. We are much more independent if we work. For instance, I can get by because I work, whereas a woman who works at home, well, she has to accept everything. I think we are freer, and I think that helps. "98

This human security frame put the accent on the $I$ as an individual female and not on the We as a collective femininity. Their proponents do not put the accent on strategic framing of women as heroines in post-conflict contexts, but they emphasize practical and material needs based on the ordinariness of the women involved, and link these everyday experiences with broader national, regional and global political processes and structures:

"If you are not economically active, even at the level of your home, there is no respect. Your husband does not respect you. [...] So this is an opportunity to different levels of violence: violence at the level of the home, violence at the level of the environment, at the regional level, etc. Because if you are economically weak, they can come to you and convince you of everything. But if you are economically strong, then you can negotiate. ",99

\footnotetext{
${ }^{98}$ Interview (d), a legal affairs staff at national women association in Bujumbura, Burundi, 12 December 2012

${ }^{99}$ Interview (f), a project manager of a national women organisation in Bujumbura, Burundi, 8 April 2013
} 


\title{
Gender Security as a transformation of spaces and structures
}

This frame where women are understood as community mediators is mostly found amongst local grassroots women groups. The frame puts an emphasis on socioeconomic security and it considers the habits and institutions of the current political and social system as major impediments for its achievement. If the frame on gender security as freedom is based on changing the legal status of women as a remedy against women's subordination, this frame seeks recognition of the way in which post-war gender arrangements contribute to the perpetuation of socio-economic inequalities.

"When we came back here after the war, we were asking for money on the streets. But people were chasing us [her and her children] because we did not have a place to live and nobody [a husband] to protect us. Life is still hard, hard. The women have helped me be part of their cooperative." 100

\begin{abstract}
Although it shares with the gender security as inclusion frame the belief in a greater common femininity, it conceptualizes war and peace, private and public as a continuum rather than as opposites and in so doing, it goes against traditional conceptions of violence and security as an identifiable thing:

"Security is a very wide term. Security goes together with peace, which is at the same time an interior peace and a material peace. [...] The bare minimum for a woman to feel in security is to have food security and the security of having a home, the security to have something to wear, to be able to be at home."
\end{abstract}

\footnotetext{
100 Interview (g), activist from grassroots group, Cibitoke province, Burundi, 9 April 2013

101 Ibidem
} 
Femininity is synonym here of an aptitude for the relationship between the local communities and the land they live in. This makes a collective "we, the women" suitable agents for the management of resources:

"Now women at the community level have understood that this is not the problem that it is not because you are a Hutu or a Tutsi that we have to kill each other. The problem is the bad management of resources; it is the bad management of resources at the community level. Now women have understood that and they are raising awareness to other women indicating that we need to take care of the management of resources. "102

Drawing on recent systematizations of poststructuralist-influenced feminist methodology in gender and security studies that enquiry toward the discursive construction of master frames and (gendered) subject positions, I have shown in this section that there is not one, but at least five different discourses on gender security that could be used as master frame for the transnational campaign for the implementation of UNSCR1325 in Burundi and Liberia. The next section explains how in both countries the result of the intra-network negotiations on which gender security logics will compose the master frame resulted in a rebound and not in a boomerang effect.

\section{The Rebound Effect: Naming lost boomerangs}

In this section, I suggest that processes of alliance making in post-conflict contexts result most likely in a rebound effect, not in a boomerang effect or in a complete lack of cooperation between international and local civil society. I argue that when international

\footnotetext{
${ }^{102}$ Interview (f), a project manager of a national women organisation in Bujumbura, Burundi, 8 April 2013
} 
activists agree to coalesce with local constituencies in order to launch a domestic campaign for the implementation of an international norm, a new dialogical process starts during which the discursive logics underpinning the master frame, and its associated subject positions and policy proposals are negotiated. That is, there is a renewal of discourses regarding what the campaign is about, in which "at least one ideational element in the idea is replaced by an element of meaning that was not present before". ${ }^{103}$ This results in either dichotomization of the members of the TAN, in absorption of one of the discourses and groups of activists by the strongest one or in a hybrid form of these two mechanisms. ${ }^{104}$ More specifically, a dichotomization of the network happens when the TAN can no longer tie together the different subject positions and discourses, and activists separate into different groups that become autonomous and pursue different ways. Here, divergences become big breaches and they tend to delegitimize the other group, "whose actions are either ignored as useless or perceived as counterproductive and even dangerous for the movement". ${ }^{105}$ This is what happened in the Burundian case when the campaign for the implementation of UNSCR 1325 became the campaign for the right to inherit. It provoked a rebound effect of the boomerang by exclusion.

In other situations, the configuration of the ideational map of discourses is such that the tension between the two main oppositional discourses disappears under the strongest, hegemonic one. ${ }^{106}$ Hence, one discourse within the network is absorbed by the other and attracts media, political and social attention. It therefore becomes more stable, being reproduced and strengthened over time. It does not allow other discursive

\footnotetext{
${ }^{103}$ Martin Carstensen, 'Conceptualising ideational novelty: A relational approach, British Journal of Politics and International Relations, 17: 2 (2015), pp. 284-297.

${ }^{104}$ Geoffrey Pleyers, Alter-globalization: Becoming actors in a global age (Cambridge: Polity, 2010).

105 Pleyers (2010), p. 185.

${ }^{106}$ Pleyers (2010), p. 191.
} 
configurations to develop. This was the case in Liberia, where the absorption provoked a rebound effect by annulment of alternative voices. As Pratt and Richter-Devroe ask: "When 1325 calls for empowering women and supporting so-called indigenous women's peace strategies, we thus need to ask critically which women and which indigenous strategies?"107 A careful examination of the interactions between local women's groups in Burundi and Liberia and international activists forming the UN NGO Working Group on WPS indicates that the fine line between the positive outcome of the boomerang effect and the less desirable rebound effect, between which strategies get accepted and which get excluded, is located between the frame of gender security as countering sexual violence and gender security as freedom.

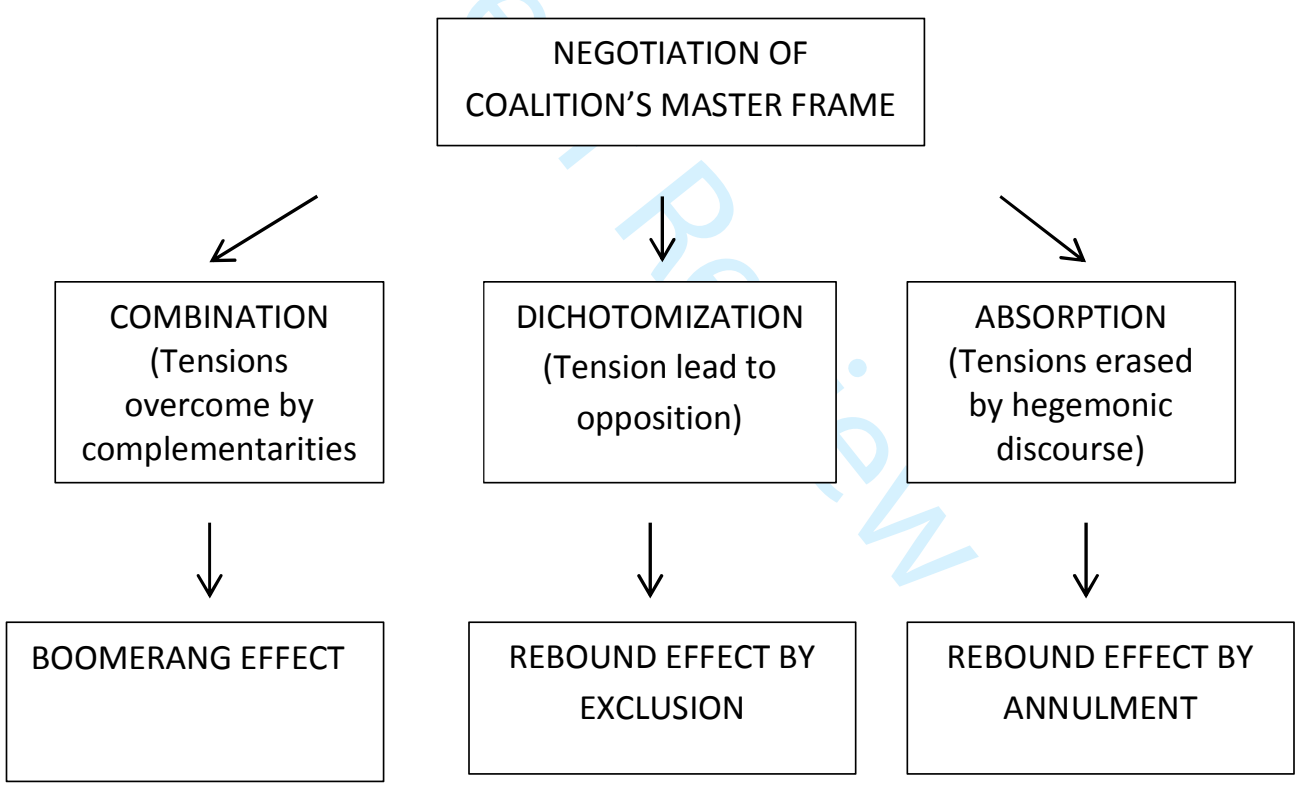

Figure 1. The negotiation process and possible results of an advocacy coalition master frame.

\footnotetext{
107 Nicola Pratt and Sophie Richter-Devroe, 'Critically examining UNSCR 1325 on women, peace and security', International Feminist Journal of Politics, 13: 4(2011), p. 498.
} 


\section{From tension to opposition in Burundi}

There is currently no law governing land inheritance in Burundi, but the customary practices exclude girls from inheritance because according to the patrilineal system, "they do not perpetuate the family line". ${ }^{108}$ The second most populated country in the African continent after Rwanda, Burundi is overcrowded and its land management system is the source of deep socioeconomic divisions that were one of the main causes of civil war. Research shows that the majority of land conflicts are conflicts amongst members of the same family, same clan and ethnicity that generate episodes of exceptional violence, ${ }^{109}$ leaving female members of the family without any chance to access family property. This also makes women more prone to sexual and gender-based violence and polygamy. ${ }^{110}$

Burundian activists have used international norms on gender equality such as the Convention on the Elimination of All Forms of Discrimination against Women (CEDAW), as well as collaborations with international organisations and NGOs as political resources for the land issue. ${ }^{111}$ After decades of advocacy that started in 1975 and the persistent failure to bring the issue of women's land inheritance to a vote at the Burundian Parliament, women's organisations found UNSCR1325 and the creation of a NAP for its implementation constituted a new opportunity to request international help from organisations that were putting in place awareness projects against gender and

\footnotetext{
${ }^{108}$ Gertrude Kazoviyo and Pélagie Gahungu, The issue of inheritance for women in Burundi (Bujumbura: FRIDE and Ligue ITEKA, 2011).

${ }^{109}$ International Crisis Group, Les terres de la discorde (I): la réforme foncière au Burundi, Rapport Afrique n. 213, (2014) p. 7.

${ }^{110}$ Association des Femmes Juristes du Burundi et Association des Juristes Catholiques du Burundi, Impact du vide juridique observé en matière des successions, des régimes matrimoniaux et des libéralités, 2012, Final report RML, p. 42.

${ }^{111}$ For a detailed account on women's collective action on land inheritance in Burundi, see Marie Saiget, '(De-)Politicising women's collective action: international actors and land inheritance in post-war Burundi', Review of African Political Economy, 43: 149 (2016), pp. 365-381.
} 
sexual violence and on women's political representation. ${ }^{112}$ Acting as a good compliant with international norms, the Burundian Ministry of Gender created in 2007 a Committee in charge of drafting and following up the implementation of the NAP. The Committee was formed by the Ministry of Gender, UNWOMEN, international NGOs part of the UN NGO Working Group on WPS, such as Femmes Africa Solidarite (FAS) and International Alert, and civil society organisations, such as Dushirehamwe, CAFOB, le Réseau des Femmes et alliées artisans de la Paix, and the Association des Femmes rapatriées du Burundi (AFRABU). During negotiations of the drafting process, women's organisations were successful in incorporating several paragraphs and proposed activities on the economic independence for women and the need to give equal rights to brothers and sisters to inherit their parents' land. ${ }^{113}$

As one member of a national women's organisation in Bujumbura ${ }^{114}$ participating in the drafting of the NAP explained, gender security in post-war Burundi could not be guaranteed unless socio-economic protection for women was enacted by law. Another Burundian activist who previously worked for an international $\mathrm{NGO}^{115}$ argued that without allowing women to own land, it did not make any sense to advocate for women's political representation through quotas: the power inequalities in the society remained untouched, preventing "effective" political participation in peacebuilding and development. The NAP gave new momentum to the advocacy campaign on land inheritance in the early 2010's and international activists started a coalition with women's organisations under the presidency of Association des Femmes Juristes du Burundi [Burundi Association of Female Lawyers] and the vice-presidency of ACORD

\footnotetext{
112 Interview (c)

${ }^{113}$ Burundi National Action Plan (2009)

${ }^{114}$ Interview (f)

${ }^{115}$ Interview (h), woman activist, ex- staff member of an international NGO Burundi desk office, Bujumbura, 12 April 2012
} 
Burundi to fund awareness campaigns and studies as well as to draft a joint action plan in 2011. However, international funding and support on the right to inherit campaign ended abruptly after a public speech on transitional justice on 28 July 2011 by the President of the Burundian republic, Pierre Nkurunziza. ${ }^{116}$ The President ordered the immediate cease of all activities concerning the legislative and political process on land inheritance, arguing that they were a source of ethnic and political conflict.

Although the campaign has not been successful up until now, by reinterpreting UNSCR 1325 and formulating a critical feminist conceptualization of security in which socioeconomic rights are taken into account, women's organizations in Burundi have utilized the Resolution and the NAP to provide an element of international legitimacy to support visions of how future gender security can be achieved. Ultimately, a new period of intranetwork negotiation between local women's organisations and international activists on how to proceed followed the Presidential speech. Several women's organisations complained that although a good number of NGOs were critical in their reports and several governments pushed the Burundian government to improve the social, economic and political situation of women in the country, they failed to spend more resources and efforts on what became a more controversial issue than previously expected. ${ }^{117}$ Donors and many INGOs decided to stop collaborating with local activists in advocacy projects for the drafting of a law on inheritance provoking a rebound by exclusion. One of my interviewees deplored the situation and indicated that what seemed to be an agreement between international and national activists, was no longer so after intervention of Pierre Nkurunziza. ${ }^{118}$

\footnotetext{
${ }^{116}$ Interview (d)

117 Interview (d)

118 Interview (f)
} 
As the national government asked for the campaign to stop, the response of UNWOMEN and international NGOs has been very ambiguous and consists of a disaggregation of discourses and campaigns on security and development: On the one hand, they have kept advocacy work for participation of women in electoral processes and awareness-raising against gender violence under programs funded by implementation funds for WPS projects, and therefore under a gender security frame. On the other hand, they have de-securitised the campaign on inheritance rights by reframing (economic) gender security into "women's economic empowerment". That is, while land rights for women was an objective of the Burundian NAP on UNSCR1325, once the Burundi government opposed its implementation and local women activists sent a boomerang to international organisations, the response from the TAN was to change venue and to focus on another international agenda on female empowerment underpinning a logic of "smart economics" that assumes that investing in girls and women promotes a society's economic growth. Indeed, the Burundi Development Partner Conference in Geneva on 29th and 30th October 2012 was organised with the objective of mobilising financial support for Burundi's second Strategic Framework for Growth and Poverty Reduction (SFGPR II), which outlines the government's commitments for the country's economic growth and development from 2012 to 2016. This Framework is a requirement set up by donors and lenders, such as the International Monetary Fund, before low-income countries can receive aid. Funded by the UN and supported by International Alert, a group of Burundian women travelled to Geneva and read a declaration in which they advocated for access to "means of production and land" for rural women as well as other socio-economic rights under the national SFGPR II. However, advocating for smart economics and women's access to micro-credits and other small-scale activities so that they can participate in neo-liberal economics is not 
the same as advocating for equal rights. This advocacy fails to convey a transformative understanding of gender security in which political stability and socio-economic development are seen as intertwined. ${ }^{119}$ In this way the boomerang rebounds as local activists can no longer use the international agenda on WPS to advocate for gender security. What is more, the alternative frame of women's economic empowerment does not target all women, but only those that qualify as "women from rural communities" targeted by the SFGPRII.

\section{Hegemonic captivation in Liberia}

Liberia's strong women's movement for peace played a key role in putting an end to the civil war in 2003. The movement was given international recognition in 2011 after the film entitled Pray the Devil Back to Hell acted as the catalyst for a Nobel Peace Prize to the social worker Leymah Gbowee and leader of WIPNET (Women in Peace Building Network), an association created out of the Women of Liberia Mass Action for Peace. The movement mobilized a wide set of symbolic resources. Apart from slogans and songs, these women activists wore white t-shirts and white handkerchiefs symbols of unity during their peace campaigns. In an almost unavoidable way, they linked war violence to sexual and gender-based violence, and security to physical integrity and to participation in public and political affairs. Moran and Pitcher claimed "that there was far more peace-oriented activity by explicitly women's organizations going on in Liberia; furthermore, these organizations existed at all levels from the most powerful urban elites to illiterate villagers". ${ }^{120}$ International funding and peace-oriented projects directed at building capacity with the organizations behind the 2002 Women Mass Action for peace, such as WIPNET, followed. Inevitably, the international master frame

\footnotetext{
${ }^{119}$ Claire Duncanson, Gender and Peacebuilding, p. 138.

${ }^{120}$ Mary Moran and Anne Pitcher, "The "basket case" and the "poster child": Explaining the end of civil conflicts in Liberia and Mozambique', Third World Quarterly, 25: 3 (2004), pp. 504.
} 
of gender security as defined by the inclusion and of women in this capacity building as good peacemakers was rapidly adopted by the main local associations. ${ }^{121}$

Local and international activists alike pointed at the empowerment of rural women and grassroots peace movements through the Peace Huts project as the biggest success on the campaign for the implementation of UNSCR1325 and the Liberian NAP. These Peace Huts are community-led peace building groups, established by WIPNET and financially supported by UNWOMEN. ${ }^{122}$ A group of women meet on Thursday mornings in these Peace Huts to discuss the diversity of conflicts that had arisen within the community, issues related to rape, land or tribal problems. In addition, Peace Huts were used in the majority of cases to fight the issue of domestic and gender-based violence: "the issue of domestic violence is a security issue, because after the conflict domestic violence has gone up, so it is a personal security issue for women. I wanted to flag that in the advocacy that we did on $1325^{\prime \prime}{ }^{123}$ It is easy to find the link between Peace Huts and the transnational discourse on international security, peace-building and gender that see women as peacebuilders and gender security as inclusion. Indeed, the Global Study on the implementation of UNSCR $1325^{124}$ used Peace Huts as the example of grassroots women's organizations inclusion in post-conflict peacebuilding and the collaboration of these grassroots groups and the Liberian National Police on sexual and gender-based violence prevention.

\footnotetext{
${ }^{121}$ Petra Debusscher and Maria Martin de Almagro, 'Post-conflict women's movements in turmoil: the challenges of success in Liberia in the 2005-aftermath', The Journal of Modern African Studies, 54: 02 (2016), pp. 293-316.

${ }^{122}$ For more information on the Peace Huts, see UNIFEM (October 2007) Women building peace and preventing sexual violence in conflict-affected contexts: A review of community-based approaches, at http://www.unwomen.org/ /media/Headquarters/Media/Publications/UNIFEM/0202 WomenBuilding PeaceAndPreventingSexualViolence_en.pdf

${ }^{123}$ Interview (i), staff member of a women's community based radio station in Monrovia, Liberia, 1 September 2013

${ }^{124}$ UNWOMEN, Preventing Conflict, Transforming Justice, Securing the Peace (New York: UN, 2015), p. 204.
} 
Significantly, the Peace Huts were set up through the National Rural Women Structures of Liberia, a civil society organisation created by the Ministry of Gender. ${ }^{125}$ The Structures were founded in 2009 as a way to channel funding to the internationally admired superheroines ${ }^{126}$ and are composed of county divisions under a national presidency. The Ministry directly appoints the leaders of each of the divisions. The Structures also act as a link between rural women grassroots groups and international NGOs. It is difficult to see how after having been selected by the national government, they can provide an independent account on the situation of rural women and their priorities in the country. That is, the few alternative discourses that could appear and that differed from gender security as inclusion or gender security as equality were erased or captivated by hegemonic governmental and international forces. The discourses and related subject-position, offered by the grassroots are, once again, coopted and silenced. Women become community mediators, as the discourse on gender security as transformation proposes, but they do so under the direction and rules of a national structure controlled by the Ministry of Gender and funded by the international community.

When asked whether there is any campaign for the enforcement of the Liberian inheritance law, one staff member of an international NGO country office in Liberia commented that there was no organisation working on the issue, and that rural women

\footnotetext{
${ }^{125}$ This data was presented by the Liberian Minister of Gender at the time, Julia Duncan Cassell, at the $56^{\text {th }}$ session of the Commission on the Status of Women: "The Empowerment of Rural Women and their role in poverty and hunger eradication, development challenges and the way forward", available at: \{http://www.un.org/womenwatch/daw/csw/csw56/general-discussions/member-states/Liberia.pdf\} accessed 09 August 2014.

${ }^{126}$ Laura Shepherd, 'Sex, Security and Superhero (in) es: From 1325 to 1820 and Beyond', International Feminist Journal of Politics, 13: 4(2011), pp. 504-521.
} 
were "looking at natural resource management problems". ${ }^{127}$ This is reminiscent to the change of discourse in Burundi from the right to inherit to access to resources. Peace Huts are the example I use to demonstrate how the subject position of Liberian women as peacebuilders as it appears in the international peace-building discourse coordinates and blurs different experiences and distorts what subsequently can and will be advocated for. The idea of mediation through women as an approach to reconstructing social relations and building civil society has been naturalised through the use of the ancestral Palava Huts transformed into Peace Huts. No other collective identity is possible and a certain understanding of gender security prevents other voices coming directly from the political subject of (in) security from emerging.

This does not mean that there has not been international help for campaigns on socioeconomic rights for women. To the contrary, once the peace accords that put an end to the Liberian civil war were signed in 2003, the biggest objective of the women's movement in the country - supported by international activists - was to have a more institutionalized participation in political and economic affairs for women. They campaigned for access to land, employment and the enforcement of existing equality laws. ${ }^{128}$ Indeed, WIPNET exposed some rhetoric in the "Women's national agenda for peace, security and development in post-war Liberia" in which they argued that the control over means of production and access to land and other primary resources was considered key in order to achieve economic equality. ${ }^{129}$ Nevertheless, these petitions are not interpreted under a discursive framework based on Security Council resolutions,

\footnotetext{
${ }^{127}$ Interview (j),local staff from the local branch of an International NGO in Monrovia, Liberia, 8 August 2013

${ }^{128}$ Veronika Fuest, 'Contested Inclusions: Pitfalls of NGO Peace-Building Activities in Liberia', Africa Spectrum, (2010), pp. 3-33.

${ }^{129}$ WANEP and WIPNET, Women's National Agenda for Peace, Security and Development. Adopted on 30 March 2006, presented to the Government of the Republic of Liberia (Monrovia: Women in Peacebuilding Network, 2006).
} 
but on a "national agenda", and the socio-economic realm is clearly separated from what are considered high politics issues on war and peace. If the internationals use the boomerang to help on the socio-economic equality struggle, a securitization of the matter that could concede a global nature to it is excluded. The pass of a land inheritance law that regulates women's marriage rights, rights to property, and access to their children after divorce or death of the husband has not been much of a problem in Liberia. The law passed without too much resistance in 2003 , although there is no enforcement mechanism and rural communities follow customary practices of inheritance that tend to be detrimental to women. ${ }^{130}$

\section{Conclusion}

This article argues that one can understand better the outcomes of norm diffusion by using a discursive approach to study the internal power dynamics inside a transnational advocacy campaign. Constructivist approaches to international norm diffusion have focused mainly on understanding how norms emerge, cascade, become institutionalised and then accepted as given, with no more room for interpretation during implementation. In particular, I first suggest that norms are processes and not things whose meaning remains fixed once they have been institutionalised. To the contrary, their content may change during implementation campaigns during which there will be attempts to stretch their meaning. Second, I propose that TANs are not stable platforms of ideas and identities. Rather, these are co-constituted through discursive performance.

In both countries, the challenges and controversies regarding the transnational campaign for the implementation of UNSCR 1325 on WPS are translated into a struggle in which competing discourses within the advocacy network resulted in the production,

\footnotetext{
${ }^{130}$ Interview (k), staff member and lawyer of a women professional association in Liberia, Monrovia, 6 August 2016.
} 
circulation and naturalization of hierarchical power relations that condition the political economy of the global order. The Burundi case study shows patterns of exclusion and dichotomization of local women activist discourses in the implementation of UNSCR1325 and the fluctuation of the internal dynamics between members of the advocacy campaign. It also demonstrates the abilities of Burundian activists to denaturalise mainstream discourses around gender and security by trying to push for a frame were gender security is understood as freedom. The Liberia case study shows patterns of hegemonic captivation and annulment of other possible emerging discourses as international and governmental organisations control the availability of subject positions. In sum, local women's organisations looking for "a more radical agenda of social and political transformation" than that offered by the "liberal peacebuilding agenda" of UNSCR1325 will only find their boomerang bouncing back. ${ }^{131}$ The solidarity links created in the campaign are not necessarily framed in the Burundian or Liberian context or through their own framing of the campaign. Rather, the complexity of the security situation in Burundi or Liberia is framed through concepts that resonate with global audiences and donors. The situation on the ground is reconstructed through a selection of events and key problems in order to create solidarity across boundaries and pass the message to those with the power to allocate resources and attention. A certain "gender security", the acts of violence committed against women at war, and the need of quotas to solve the problem, act as reference point for the solidarity. Nevertheless, it is not clear whether these reference points are aligned with local experiences and claims.

\footnotetext{
${ }^{131}$ Pratt and Richter-Devroe, cited in Soumita Basu, 'The Global South writes 1325 (too)', International Political Science Review, 37:3 (2016), pp. 362-374.
} 
The article advocates for a discursive approach to norm diffusion theory that makes productive power visible in order to highlight the fact that norms do not spread in the absence of politics. Such an approach enables the researcher to name "lost boomerangs" by using the concept of the rebound effect and to argue that in post-conflict contexts, the most likely outcome is a rebound, and not a boomerang effect. In sum, such an approach can offer a situated account to the study of transnational advocacy networks and their role in the spreading of international norms. Additionally, it offers possibilities for theorizing the encounter between transnational and local activists in which more space is left for the experience of difference in processes of collective identification and discourse normalization. 